\title{
二分脊椎に伴う麻痺性側弯症に対する手術的治療
}

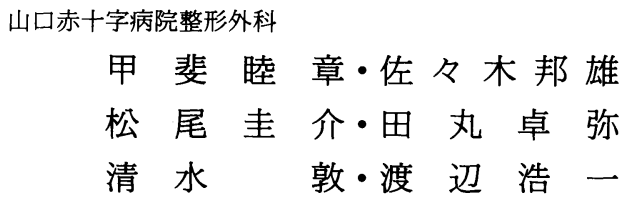

\section{Surgical Treatment of Paralytic Scoliosis Associated with Myelomeningocele}

by

\section{Mutsuaki Kai, Kunio Sasaki, Keisuke Matsuo,} Takuya Tamaru, Atsushi Simizu and Koichi Watanabe

Department of Orthopaedic Surgery, Yamaguchi Red Cross Hospital

\begin{abstract}
Paralytic spinal deformities associated with myelomeningocele present several difficulties in the treatment.

Eleven years old boy suffered from paralytic lordoscoliosis with spina bifida below L5. Preoperative scoliosis was 124 degrees, pelvic lumber angle 33 degrees and sacral inclination 60 degrees.

Tow-stage operation was done.First, anterior release and fusion by use of Zielke instrumentation was performed. Second, Luque instrumentation by Galvestone technique and Harrington instrumentation was done.

During operations, small vertebrae and weakened body around the apex were main problemes fou instrumantation.

One year afer the operation bony union was achieved. Finally, scoliosis was corrected $40 \%$ ( 75 degrees), pelvic lumbar angle 45\% (18 degrees) and sacral inclination was 11 degrees.He gained balanced appearance of his back and could sit well.
\end{abstract}

緒

麻疸を伴う二分脊椎に合併する側弯は, 治療上困難 な面が種々存在する．今回われわれは，第 4 腰椎以下 の頝性二分脊椎, 第 5 腰遷節レベル以下の弛緩性麻痺 に合併した麻痺性側弯に対し, 装具療法後手術的治療 を施行したので治療経過および手術の時期・手術法に 検討を加え報告する。

1. 症例

11 才男性．家族歷）特記すべきことなし．既往歴） 生下時食道閉鎖に対し食道再建術，2 才時両内反足に 対し矯正術，および両股脱臼障害に対し両大腿骨内反 骨切り術を施行す，現病歷)生下時, 頝性二分脊椎 (脊 䯣破裂）に対し閉鎖手術を受ける。1才時，側弯に気
付き当科初診, 胸腰椎移行部に $45^{\circ}$ の側弯を認める. 以 降 under arm brace を中心とした装具療法を行うも側 弯は進行し, 10 才から 11 才の 1 年間に急速に $88^{\circ}$ から $124^{\circ}$ と増悪した為, 11 才時手術目的にて入院となる.

（図 1 ）入院時現症）通常は車椅子を使用. 歩行は両 下肢にSLB 装着し, 両ロフストランドクラッチ使用に て可能。脊椎は, 右凸胸腰椎部麻㽻性側弯を認め腰椎 前弯の著名な増強を見る，皮虙には，手術疫痕が認め られる他には特記すべき所見なし，神経学的には，L 5 レベル以下の完全麻痺であった.

入院時レ線前後像にて側弯は $124^{\circ}$,骨盤傾斜は $33^{\circ}$ で

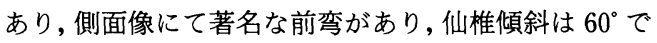
あった。 又, T1-decompensation は $35 \mathrm{~mm}$ であった。

2. 手術法 


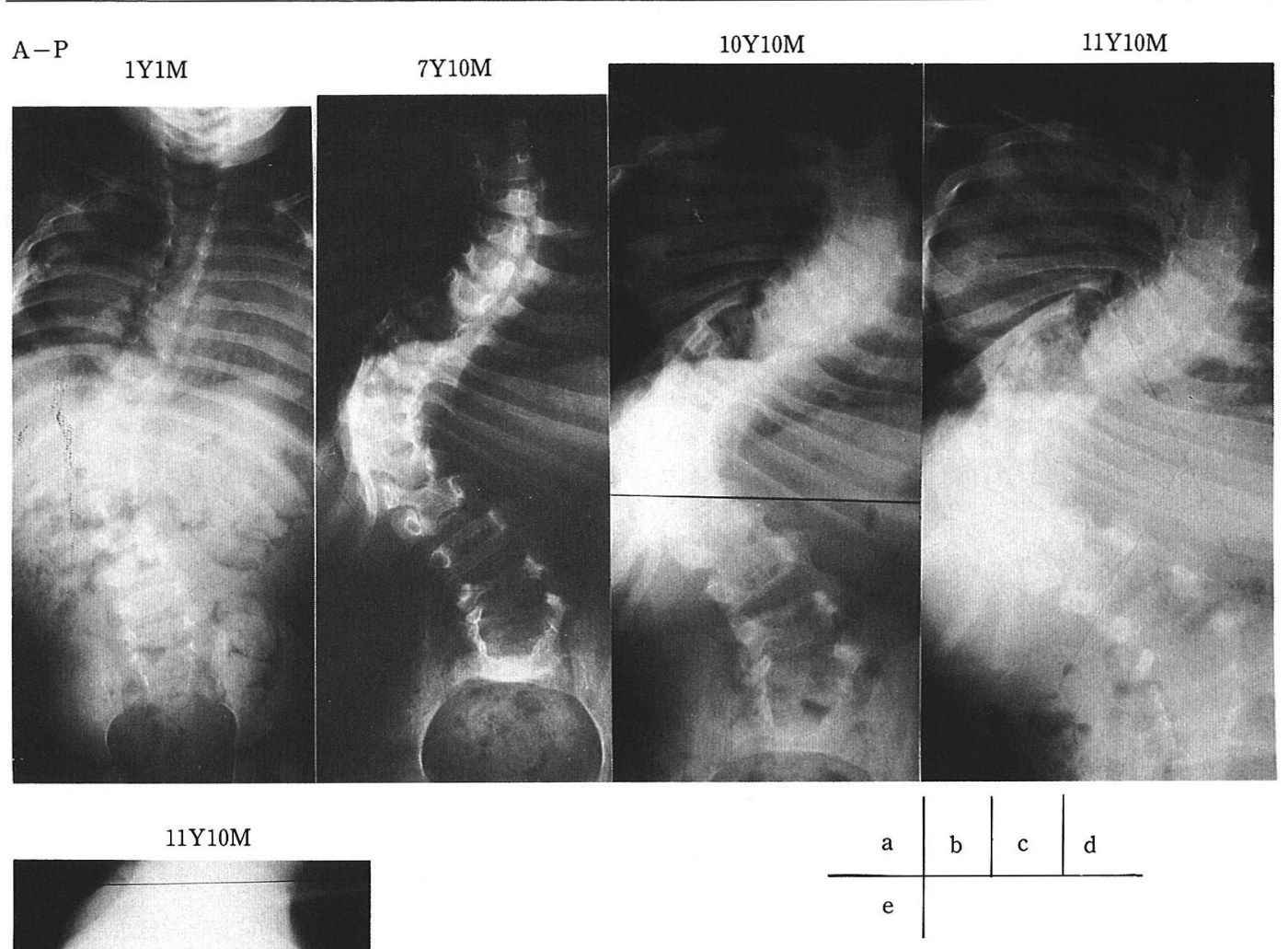

$$
\begin{aligned}
& \begin{array}{lllllllllllllll} 
& \text { a } & \text { c } & \text { d }
\end{array} \\
& \text { scoliosos } 45^{\circ} \quad 75^{\circ} 88^{\circ} \quad 124^{\circ} \\
& \text { (T8 L4) } \\
& \text { PLA } \quad 11^{\circ} 35^{\circ} 24^{\circ} 33^{\circ} \\
& \mathrm{e} \text { : 著明な腰椎前弯及び仙椎の水平化をみる。 } \\
& \text { sacral inclination } 60^{\circ}
\end{aligned}
$$

図 1 K. K. male

手術は二段階に分け行った。1段階手術は, 経胸膜・ 腹膜外経路にて第 8 胸椎より第 4 腰椎までを展開。同 範囲内の椎間板摘出後, Zielke 法 (VDS) による矯正 を行う。矯正時第 $8,9,10$ 椎体は骨折を生じ, 内固 定は行えなかった。最終的にVDSによる矯正固定は，
第 $11 / 12$ 胸椎間より第 $3 / 4$ 腰椎間に行った。椎間の骨 移植は，全範囲に施行した。

2 段階目手術は 3 週間後に施行. Galveston 手技に よるLuque instrumentation を第 2 腰椎より骨盤まで 施行. 術中, 椎弓欠損は第 4 腰椎以下に存在し, Luque 
表 1 K. K. male [\% correction and\% loss of correction]

\begin{tabular}{|c|c|c|c|c|c|}
\hline & & \multicolumn{2}{|c|}{ scoliosis } & \multirow{2}{*}{ PLA* } & \multirow{2}{*}{$\mathrm{SI}^{* *}$} \\
\hline & & $\mathrm{T} 1-\mathrm{T} 7$ & T8-L4 & & \\
\hline$\%$ correction & $\begin{array}{lll}\text { 第 } 1 \text { 回術 後 } \\
\text { 第 } 2 \text { 回術 後 } \\
\text { 最 } & \text { 終 } & \text { 時 }\end{array}$ & $\begin{array}{l}1 \% \\
29 \\
3\end{array}$ & $\begin{array}{l}27 \% \\
50 \\
40\end{array}$ & $\begin{array}{l}45 \% \\
61 \\
45\end{array}$ & $\begin{array}{l}65 \% \\
80 \\
80\end{array}$ \\
\hline \multicolumn{2}{|c|}{$\%$ loss of correction } & $90 \%$ & $21 \%$ & $25 \%$ & $0 \%$ \\
\hline
\end{tabular}

* ; pelvic-lumbar angle, ** ; sacral inclination

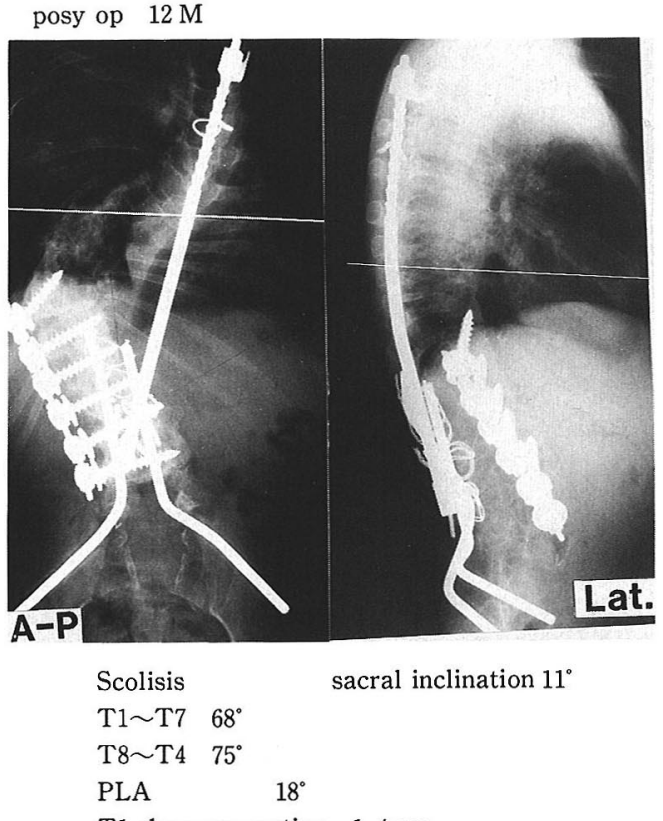

T1-decompensation $1.4 \mathrm{~cm}$

図 2 K. K. male $11 \mathrm{Y} 10 \mathrm{M}$

$\operatorname{rod}$ の椎弓支持部位は第 5 腰椎の残存椎弓とし, sublamina wiring は第 12 胸椎より第 3 腰椎々弓に施行し た. Harrington instrumentation は第 2 胸椎より第 3 腰椎に single distraction rod を使用した。術中, 胸椎 下関節突起の骨折を生じ, 上位 hook は bifid type を使 用, rod を第 4 胸椎棘突起基部に通した wire にて締結 した。instrumantation 領域には銀行骨にて facet fusion および後側方固定を施行し, 腰仙椎部には充分 の骨移植を行った。

\section{3. 術後経過等}

術中出血量は，1段階手術 $1,000 \mathrm{~m} 1 ， 2$ 段階手術 $1,370 \mathrm{ml}$ であった。1 段階手術後, 血胸による呼吸障 害を来すも保存的治療で対処した。 2 段階手術後は,
1 週間のベット上安静の後, total contact type の硬 性装具を使用し起坐開始. 9 力月後に部分除去, 12 力 月後で完全除去した。

結果

側弯は T $1 \sim 7$ で術前 $70^{\circ}$ から最終時で $68^{\circ}, \mathrm{T} 8 \sim \mathrm{L} 4$ では, $124^{\circ}$ から $75^{\circ}$, 骨盤傾斜は $33^{\circ}$ から $18^{\circ}$, 仙椎傾斜 は $60^{\circ}$ から $11^{\circ}$ となった。

\% correction（術前角度-測定時角度/術前角度 $\times$ 100）および \% loss of correction（最終角度一最大 獲得矯正角度 $/$ 最大獲得矯正角度 $\times 100$ )を求めた。 (表 1) T1 7 の側弯矯正は最終時ほとんど得られず， 2 段階術後得られた角度は経過中袁失した。 T8〜 L4 の主 カーブは一段階術後 $27 \%$ ，2 段階術後 $50 \%$ と矯正さ れ，最終時 $40 \%$ の稪正率であった。骨盤傾斜および仙 椎傾斜はそれぞれ $45 \%$ ，80\%の矯正率であった。最終 時のレ線扔よび普通写真を示す. (図 2，3)

考察

頝性二分脊椎に伴う脊椎変形は, 治療上種々の問題 点を有している。春柱変形は，麻疩のレベル・骨奇形 （後方骨欠損も含め）に主として左右され，変形は多 くの例に扔いて生下時より存在する。变形は進行性で あり，骨盤帯をも含めた変形として考慮し治療する必 要がある1”。

今回経験した症例は, 腰椎前弯増強十高度側弯例で あり，一定期間装具療法にて進行を防止出来ていたと は考えられるも，効果としては充分ではなかった．9 〜10 才時, 高度カーブおよび growth spurt に入る時期 と一致して著名な変形進行をみた。装具療法は一応選 択されるべさ方法であるが，麻痺レベルおよび变形の 程度を考元使用すべきである。著名な側弯例において は，装具療法は効果が少ないであろう。個々の症例の 

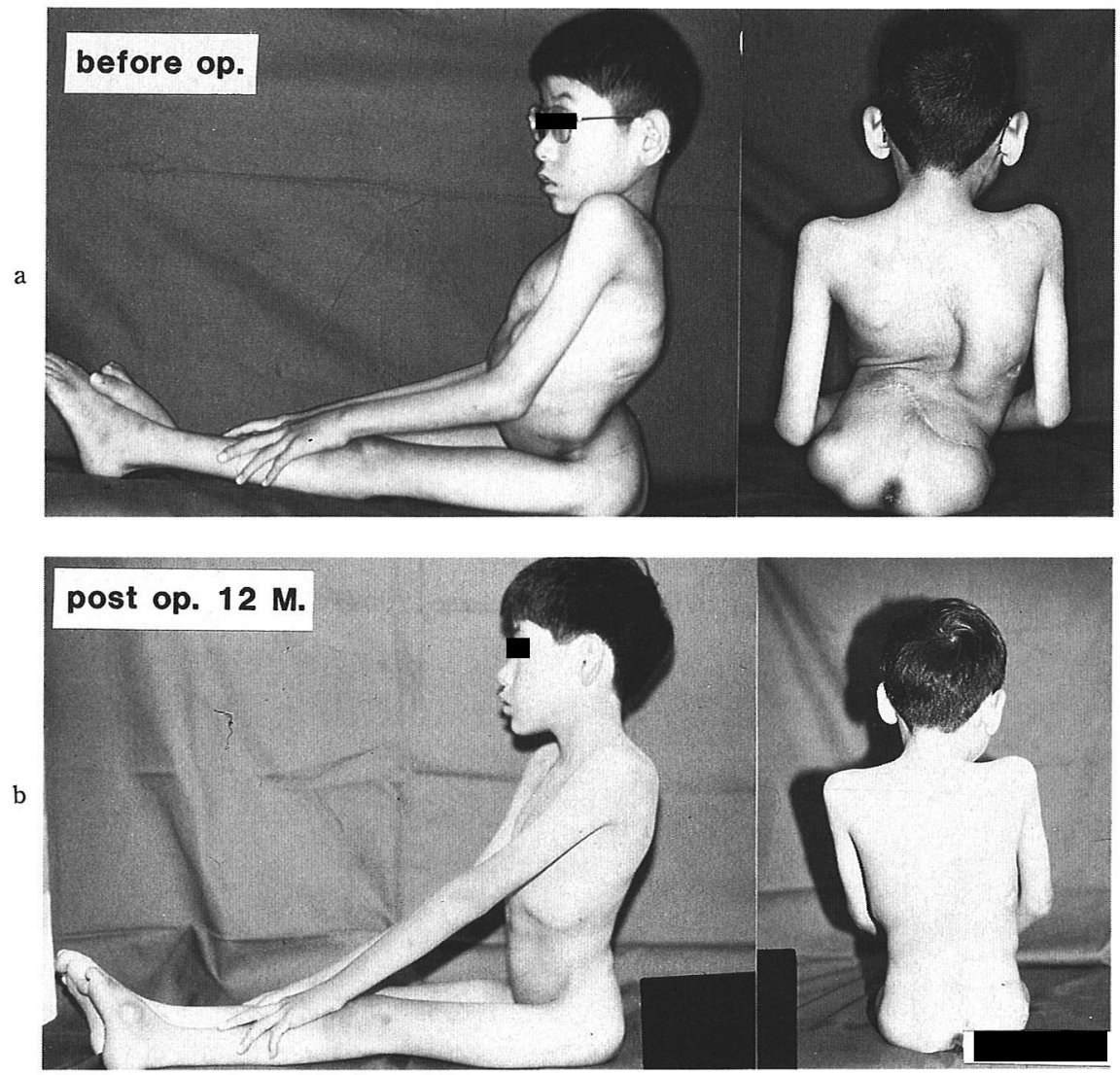

図 $3 \longrightarrow$ male

a : 11 才 10 カ月 術前

b : 12 才 10 力月 術後 12 力月経過時

経過を, 経年的に充分評価し, 装具療法から観血的治 療の時期を決定する必要がある。

変形の進行状態により手術時期は決定されるが，手 術方については，変形の要素・骨の大きさを考慮する 必要がある。われわれの症例における最大の問題点は, 手術的治療時での所見でも述べたように，骨の小さい ことと, 椎体の脆弱性にあった。今回の症例のような 変形においては, 前方・後方よりの矯正固定は必須の ものと思われるが, 椎体固定器具のもうすこし小さい ものが望まれた. Cotrel Dubossel instrumentationの 使用も検討されているが instrumentation と骨の大きさ の検討および骨移植においての充分の考慮が必要とな ろう。

このような症例に伴う骨奇形を伴わない腰仙椎の変 形に対しては， O’ brein が述べている如く腰椎部の変
形矯正にて満足すべき aligmment の獲得が可能であつ た2)

われわれの症例の最終結果は満足すべきものでなか ったが，著名な腰仙椎部変形は矯正固定された。今後 の問題としては，本症例はまだ成長の要素を充分残し ており，充分な経過観察を必要とする。

頝性二分春椎の脊柱変形に対しては，脊柱変形矯正 の問題のみならず，両下肢の問題，泌尿器的あるいは 神経学的面よりもアプローチが必要である゙”。

$$
\text { 結語 }
$$

1. 麻痺を伴う二分脊椎に合併した麻痺性側弯 (lordoscoliosis）例（11才，男性）に対し 2 段階手術前方 〜後方による矯正固定術を行った。

2. 矯正固定法として, 前方は Zielke 法, 後方は, 
Luque 法 (Galveston 法) と Harrington 法を用いた。

3. 最終矯正率は, 側弯 (T8～L4) $40 \%$, 骨盤傾斜 $45 \%$, 仙椎傾斜 $80 \%$ \%でり, 矯正襄失率は, それぞれ $21 \%, 25 \%, 0 \%$ \%っった。

4. 本症例における治療経過中の問題点について検 討を加えた。

\section{参 考 文 献}

1）村地俊二：Spinal dysraphismにともなう脊柱変形. 整形外科MOOK, $18: 300-318,1981$.

2) O' brien, J. P., et al. : Paralytic Pelvic Obliqity. J Bone Joint Surg 57-A : 626-631, 1975.
3) Osebold, W. R., et al.: Surgical Treatment of Paralytic Scoliosis Associated with Myelomeningocele. J Bone Joint Surg 64-A : 856-856, 1982.

質 問 福岡こども病院 藤井 敏男 二分脊椎の進行する側弯に対して, 観血的治療の適 応時期についてどうお考えですか.

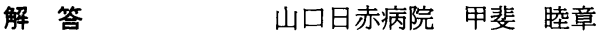
手術手技上，患者の成長（椎体の大きさも含めて） を待っていた。しかし側弯が 1 年間で $88^{\circ}$ から $124^{\circ}$ と 進行したため 11 才 10 カ月日に手術を行った。 